\title{
Effects of feeding alfalfa stemlage or wheat straw for dietary energy dilution on nutrient intake and digestibility, growth performance, and feeding behavior of Holstein dairy heifers
}

\author{
Huawei Su, ${ }^{*}$ Matt S. Akins, ${ }^{* 1}$ Nancy M. Esser,‡ Robin Ogden,§ Wayne K. Coblentz,§ Kenneth F. Kalscheur,\# \\ and Ron Hatfield\# \\ *Department of Dairy Science, University of Wisconsin, Madison 53706 \\ †State Key Laboratory of Animal Nutrition, College of Animal Science and Technology, China Agricultural University, Beijing 100193, China \\ $\ddagger$ Marshfield Agricultural Research Station, University of Wisconsin, Marshfield 54449 \\ §USDA-Agricultural Research Service, US Dairy Forage Research Center, Marshfield, WI 54449 \\ \#USDA-Agricultural Research Service, US Dairy Forage Research Center, Madison, WI 53706
}

\begin{abstract}
Feeding high-quality forage diets may lead to excessive weight gains and over-conditioning for dairy heifers. Restriction of energy density and dry matter intake by using low-energy forages, such as straw, is a good approach for controlling this problem. Alfalfa stems contain high fiber and moderate protein content and have the potential to be used to replace straw to reduce dietary energy. The objective of this study was to compare nutrient intakes, digestibilities, growth performance, and feeding behaviors of dairy heifers offered an alfalfa silage/corn silage high-energy diet (HE; $13.1 \%$ crude protein, $65.4 \%$ total digestible nutrients, $39.7 \%$ neutral detergent fiber) with 2 energy-diluted diets that replaced various proportions of the corn or alfalfa silages with either alfalfa stemlage (STM; $12.6 \%$ crude protein, $59.1 \%$ total digestible nutrients, $46.4 \%$ neutral detergent fiber) or chopped wheat straw (WS; $12.6 \%$ crude protein, $61.9 \%$ total digestible nutrients, $43.7 \%$ neutral detergent fiber). Seventy-two pregnant Holstein heifers $(16.8 \pm 1.3 \mathrm{mo})$ were stratified into 3 blocks (24 heifers/block) by initial body weight (light, $440 \pm 18.0 \mathrm{~kg}$; medium, $486 \pm 18.6 \mathrm{~kg}$; heavy, $534 \pm$ $25.1 \mathrm{~kg}$ ), with each block composed of 3 pens (8 heifers/ pen), with diets assigned randomly to 1 pen within the block. Diets were offered in a 56-d feeding trial. Both dry matter intake and energy intake were decreased with the addition of low-energy forages to the diets, but no differences in dry matter intake were observed across diluted diets. Digestibility of dry matter, organic matter, neutral detergent fiber, and apparent $\mathrm{N}$ were greater for $\mathrm{HE}$ compared with diluted diets, and for WS compared with STM. Total body weight gain (74
\end{abstract}

Received December 13, 2016.

Accepted May 15, 2017.

${ }^{1}$ Corresponding author: msakins@wisc.edu vs. $56 \mathrm{~kg}$ ) and average daily gain (1.32 vs. $1.00 \mathrm{~kg} / \mathrm{d})$ were greater for heifers offered HE compared with diluted diets. Feed efficiency tended to be less for heifers offered the diluted diets compared with HE (10.7 vs. $8.6 \mathrm{~kg}$ of feed $/ \mathrm{kg}$ of gain). Heifers did not sort for or against particles when offered HE. However, increased sorting behavior was observed for diluted diets. Compared with ad libitum feeding dairy heifers a diet with high nutrient content forages (corn silage and alfalfa silage), use of diet diluted with alfalfa stemlage or wheat straw is an effective feeding management strategy to control total daily dry matter and energy intake by increasing gut fill, and maintain desirable body condition and growth rates, even though the diluted diets had greater sortability.

Key words: dairy heifer, alfalfa stem, energy dilution, growth

\section{INTRODUCTION}

Replacement heifers represent the future potential of the dairy industry; as such, the feeding strategy for dairy heifers is to rear these animals at a minimum economic and environmental cost without reducing their future lactation performance (Hoffman et al., 2007). Dairy replacement heifers are typically fed a high-forage diet to control their body condition, while still meeting their nutrient requirements. However, in many cases, forage-based diets for dairy heifers contain significant proportions of corn silage or other high-quality forages with low NDF concentrations. As a result, the energy densities of the diet can exceed the energy requirements of heifers, and subsequently, increase weight gains and lead to over-conditioning (Hoffman et al., 2008). In addition, DMI may be inadequately restricted when forage fiber concentrations are too low. Over-conditioning of dairy heifers has been associated with various deleterious effects on their mammary development and 
subsequent first lactation performance (Hoffman et al., 1996; Lammers et al., 1999; Radcliff et al., 2000).

To solve this management problem, researchers have investigated a management approach to control energy and nutrient intakes by limit feeding a diet that exceeds energy requirements, but is restricted to 80 to $90 \%$ of ad libitum intake. Lammers et al. (1999) and Hoffman et al. (2007) used a limit feeding strategy to control growth rates of Holstein heifers and observed no negative carryover effects on first-lactation performance. Besides allowing for controlled growth rates, limit feeding also has the potential to reduce the feed costs per kilogram of gain, decrease fecal excretion, and improve feed efficiency (Hoffman et al., 2007; Greter et al., 2011; Kitts et al., 2011). In addition, limit feeding strategies also have been used successfully for ewes (Susin et al., 1995), beef cows (Loerch, 1996), and beef heifers (Wertz et al., 2001). Despite these benefits, limit-feeding dairy heifers has shown some potentially negative effects, including increased standing time without eating (Hoffman et al., 2007; Greter et al., 2011; Kitts et al., 2011), vocalization and aggressive reaching for feed (Hoffman et al., 2007), and oral stereotypies (not normally distributed behaviors; Lindstrom and Redbo, 2000). These effects can be interpreted as a sign of hunger derived from lack of satiety (Watts and Stookey, 2000; Valizaheh et al., 2008), which may be indicative of poor animal welfare. A greater potential for subacute ruminal acidosis may be present when limit feeding lower forage diets, with Moody et al. (2007) finding a tendency for longer time with rumen $\mathrm{pH}$ less than 6 for heifers limit fed $33 \%$ forage diets compared with those fed $77 \%$ forage diets. Kruse et al. (2010) found no difference in rumen $\mathrm{pH}$ when limit feeding higher forage diets with $65 \%$ forage compared with ad libitum feeding a 91\% forage diet. Use of higher forage diets for limit feeding can increase feeding and chewing time (Suarez-Mena et al., 2013). Also, addition of a low-nutritive forage in the TMR or offered separately when limit feeding can also increase feeding time and rumination (Kitts et al., 2011).

Another strategy to control caloric intake and growth rates of dairy heifers when diets contain high-energy forages is to dilute the ad libitum diet with low-energy forages, such as straw (Hoffman et al., 1996; Greter et al., 2008), corn (Zea mays L.) fodder (Coblentz et al., 2015), or eastern gamagrass [Tripsacum dactyloides (L.) L.] haylage (Coblentz et al., 2012, 2015). Use of low-energy forages increases the diet NDF content, decreases the energy content, and thus lowers DMI and energy intake when feeding for ad libitum intakes (Coblentz et al., 2015). Ad libitum feeding of an energy-diluted diet to dairy heifers has some advantages, including (1) potentially reducing feed costs due to lower intakes, (2) promoting longer feeding times, (3) controlling growth rates, and (4) providing animals with opportunities for expression of natural foraging behaviors (Greter et al., 2008). Reduction of feed costs would depend on the dilutant forage costs relative to the other diet components. There are concerns with sorting of diets containing low-energy forages, with Coblentz et al. (2015) finding that addition of straw or corn fodder to an ad libitum fed diet led to increased sorting; however, this was not found to affect variation in heifer growth. Ad libitum feeding dairy heifers with an energy-diluted ration may be a good choice to help producers potentially reduce feed costs and target energy intake for desirable growth performance.

Alfalfa (Medicago sativa L.) is generally regarded as a desirable forage for ruminants. It is well known that the nutritive value of alfalfa leaves is superior to that of the stems. The CP concentration of the alfalfa leaves is about twice that of the stems, whereas the cell-wall material and lignin fractions of the stem is 2 to 3 times greater than that of the leaves (Albrecht et al., 1987; Shinners et al., 2007). A novel harvest fractionation system has been developed by the US Dairy Forage Research Center (USDA-Agricultural Research Service) that involves stripping of alfalfa leaves from stems. The stripped alfalfa leaves then can be used as a high-CP feed to formulate diets of desired quality for cattle, or further processed to obtain value-added products for ruminants, monogastics, or humans (Shinners et al., 2007). The alfalfa stems, containing high fiber and moderate $\mathrm{CP}$ content, have the potential to be used as an option for supplying low-energy forage to reduce the energy density of heifer diets. To date, no information is available summarizing growth and behavioral responses by dairy heifers. We hypothesized that feeding a ration diluted by alfalfa stems, in a manner similar to chopped straw, would allow dairy heifers to control ad libitum intakes, and to meet their nutrient requirements for maintenance and target growth rates. Thus, the objective of this study was to compare the nutrient intakes and digestibilities, growth performance, and sorting behaviors of dairy heifers provided an alfalfa silage/corn silage high-energy diet (HE) with energy-diluted diets that include either alfalfa stemlage (STM) or chopped wheat straw (WS).

\section{MATERIALS AND METHODS}

\section{Alfalfa Stemlage Preparation}

Alfalfa leaves were harvested at a growth stage of full bloom using a prototype leaf stripper. Alfalfa stems were cut with a discbine after most leaves were removed. Stems were allowed to dry overnight before baling and individually wrapping with white polyethylene stretch 
plastic. Bales were stored indoors until being used in the feeding trial.

\section{Animals, Housing, and Diets}

All animal handling procedures for this experiment were approved by the Research Animal Resources Committee of the University of Wisconsin-Madison (protocol \#A005195). Seventy-two pregnant Holstein heifers $(16.8 \pm 1.3 \mathrm{mo})$ were stratified into blocks $(24$ heifers/block) by initial BW (light, $440 \pm 18.0 \mathrm{~kg}$; medium, $486 \pm 18.6 \mathrm{~kg}$; heavy, $534 \pm 25.1 \mathrm{~kg}$ ), with each block composed of 3 pens ( 8 heifers/pen). Diets were randomly assigned to 1 pen within each block. Heifers were housed at the University of Wisconsin Marshfield Agricultural Research Station (Marshfield, WI). Each pen had 8 freestalls with foam-core mattresses bedded with a shallow layer of dried organic solids, 8 headlocking feeding gates, and an automated mechanical alley-scraping system. Head-locks were set to allow free access and departure from the feed bunk at all times. Experimental diets were delivered as a TMR once daily between 0900 and $1100 \mathrm{~h}$, and were pushed back within easy reach of the heifers at least twice daily before orts were cleaned out of feed bunk at $0830 \mathrm{~h}$ of the following day. Feed was pushed up every 3 to $4 \mathrm{~h}$ during the day until approximately $2000 \mathrm{~h}$, then again at $0600 \mathrm{~h}$ before removal of orts. Fresh water was available without restriction at all times. A description of ingredients and nutrient composition of the diets is presented in Table 1. The treatment diets were HE (44.4\% alfalfa haylage, $55.6 \%$ corn silage), and STM or WS (diets diluted with low-energy forages). All diets were balanced to be isonitrogenous (overall mean $=12.8 \% \mathrm{CP}$ ); in addition, the diluted diets had similar caloric densities (overall mean $=60.5 \% \mathrm{TDN}$ ), which was $7.4 \%$ less relative to HE (65.4\%). The energy density of HE was balanced greater than dairy heifer requirements as a high-energy negative control treatment that causes higher gains and a negative effect on animal well-being, which can be a problem for producers with only high-quality forages available. The amount of each experimental diet offered and orts collected from each pen was recorded daily. Heifers in each of the 3 pens within a block were exposed to 1 of 3 dietary treatments, with all diets represented within each block. The experimental diets were offered for ad libitum intake. The amount of TMR offered was adjusted daily to ensure a bunk score of 2 , where $0=$ no feed particles remaining; $1=$ only scattered feed particles remaining; $2=$ numerous particles remaining, but the concrete floor is still easily visible; or $3=$ feed particles completely covering the concrete bunk floor (Hoffman et al., 2008). The diets were sampled daily at the time of feed delivery, and orts samples were collected from each feed bunk daily. Individual dietary components (alfalfa haylage, corn silage, alfalfa stemlage, and wheat straw) were obtained weekly. All these samples were immediately frozen at $-20^{\circ} \mathrm{C}$ pending further analysis.

\section{Body Weight and Size Measurements}

Initial and final BW of experimental heifers were taken for 3 consecutive days before each day's feed allotment was dispersed. All animals were weighed using a cattle chute (Real Tuff, Clearbrook, MN) equipped with an electronic scale (Tru-Test Inc., Mineral Wells, TX). In addition, body size measurements were taken for each heifer, including heart girth, hip height, and withers height. Body condition score was assessed independently by 2 trained evaluators on a scale of 1 to 5 , where $1=$ emaciated and $5=$ obese (Wildman et al., 1982); increments of 0.5 units were applied when necessary to best describe the body condition of each animal.

\section{Feed Bunk Sampling and Evaluation of Particle Size Distribution}

To assess heifer feed sorting and eating behaviors, feed bunks were sampled over a 3-d period during wk 6 of the study. Following discharge of the TMR, subsequent feed-bunk sampling times were scheduled at $1500,1900,2300$, and $0830 \mathrm{~h}$ (orts). To minimize the disruption of eating and sorting behaviors, feed bunks were sampled only once daily. Sampling times were randomized for each pen across the 3 -d period, such that each sampling time was represented on $1 \mathrm{~d}$ of the 3 -d sampling period. To obtain a sample, a scoop shovel was used to remove all the feed within the width of the shovel from the feed alley to the concrete curb. These large samples were composited and thoroughly mixed within a large plastic $70-\mathrm{L}$ tub. From the mixed contents of the tub, a subsample $(\sim 1,000 \mathrm{~g})$ was sealed in a freezer bag and frozen $\left(-20^{\circ} \mathrm{C}\right)$ pending subsequent evaluation of particle size.

Diets, bunk samples, and orts were assessed for particle size distribution using the Penn State Particle Separator, containing 3 -screens $(19,8$, and $1.18 \mathrm{~mm})$ and a bottom pan (Kononoff et al., 2003). Feed particles were separated into 4 fractions: large $(>19 \mathrm{~mm})$, medium $(<19$ and $>8 \mathrm{~mm})$, short $(<8$ and $>1.8 \mathrm{~mm})$, and fine $(<1.8 \mathrm{~mm})$. Physically effective fiber was calculated as the proportion of total particles retained on the top 2 sieves (19 and $8 \mathrm{~mm}$ ) of the separator (Lammers et al., 1996). The sorting factors in our study were calculated simply as the proportion of each particle fraction in the feed bunk divided by the proportion in the original diet (Coblentz et al., 2015). Therefore, values equal to 1.0 
indicate no sorting, whereas values $>1.0$ indicate that particles were less desirable and sorted against, whereas values $<1.0$ indicate that particles were preferred by heifers.

\section{Laboratory Analysis}

Prior to chemical analysis, TMR and orts samples were thawed at room temperature and composited by week. These weekly composites of diets and orts, as well as weekly individual dietary components, were dried to constant weight under forced air at $55^{\circ} \mathrm{C}$, ground through a $1-\mathrm{mm}$ screen with a Thomas-Wiley Model 4 mill (Thomas Scientific, Swedesboro, NJ), and then stored in sealed plastic sample bags. Samples were analyzed by the University of Wisconsin Soil and Forage Laboratory (Marshfield, WI) for (1) DM (NFTA, 2001); (2) CP by a macro-Kjeldahl procedure (AOAC
International, 1998; method 988.05); (3) NDF by the methods of Goering and Van Soest (1970) with both heat-stable amylase and sodium sulfite included within the NDF solution; (4) 48-h in vitro digestion of NDF in buffered rumen fluid using procedures described in detail by Kruse et al. (2010) and Coblentz et al. (2012); (5) ADF and ADL by the method of Goering and Van Soest (1970) without preliminary digestion in neutral detergent; (6) ash by combustion in a muffle furnace at $500^{\circ} \mathrm{C}$ for $6 \mathrm{~h}$; (7) starch (Ehrman, 1996); (8) ether extract (AOAC, 1990; method 920.29); (9) Ca, K, and $\mathrm{Mg}$ by atomic absorption spectroscopy; and (10) P by colorimetric methodology (Schulte et al., 1987). Total digestible nutrients, $\mathrm{ME}, \mathrm{NE}_{\mathrm{G}}$, and $\mathrm{NE}_{\mathrm{M}}$ of experimental diets were calculated via the summative equations (NRC, 2001), with 48-h in vitro digestion of NDF serving as a digestibility coefficient for NDF to estimate truly digestible fiber.

Table 1. Ingredient and nutrient composition of treatment diets, and chemical composition of individual dietary components based on weekly analysis

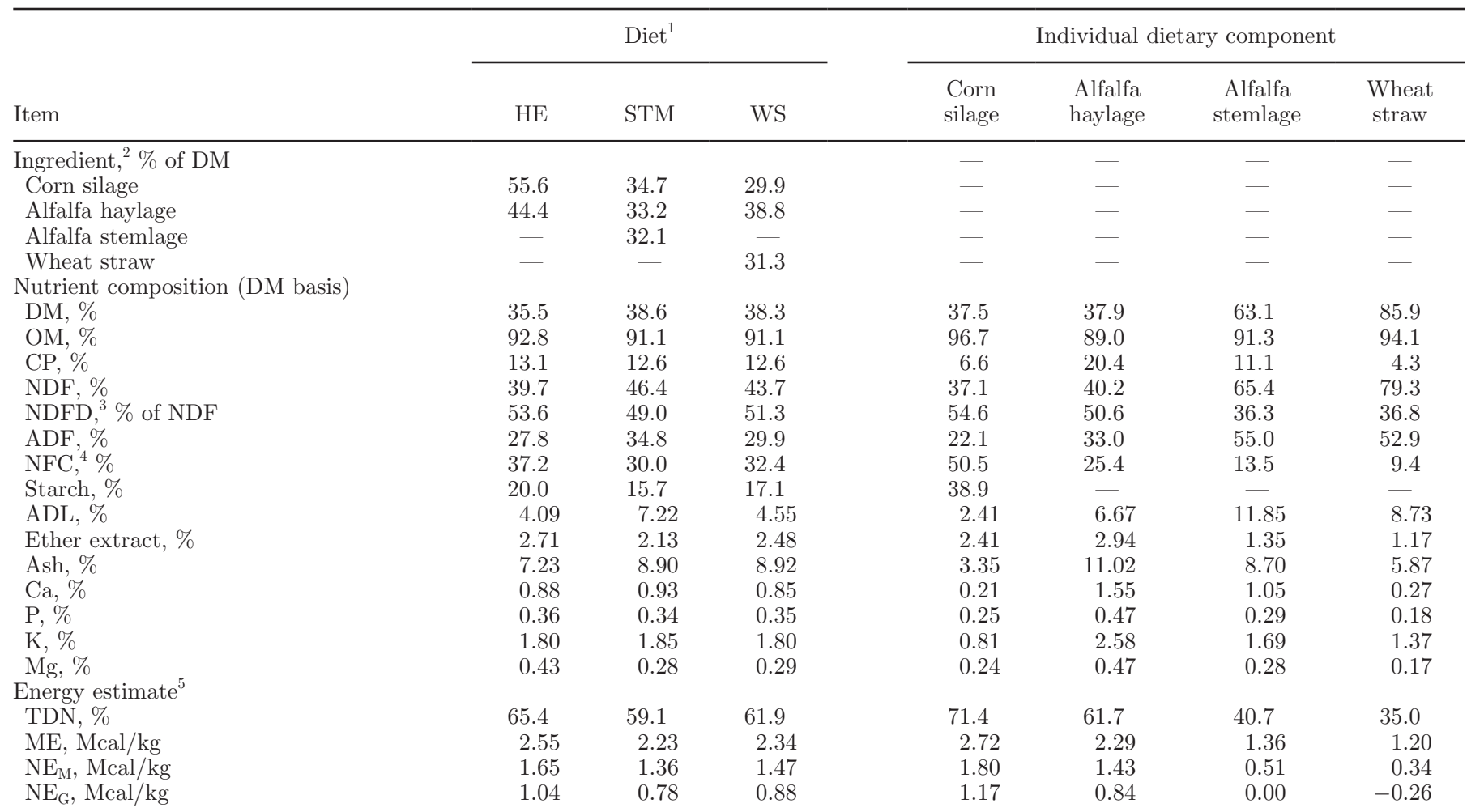

${ }^{1} \mathrm{HE}=$ alfalfa haylage/corn silage diet containing no diluting agent and offered for ad libitum intake; STM = alfalfa haylage/corn silage diet containing $32.1 \%$ alfalfa stem baleage (stemlage), and offered for ad libitum intake; WS = alfalfa haylage/corn silage diet containing $31.3 \%$ wheat straw, and offered for ad libitum intake.

${ }^{2}$ Mineral package contained $70.7 \%$ calcium carbonate, $15.1 \%$ salt, $5.04 \%$ magnesium oxide, $2.12 \%$ sulfur, $1.62 \%$ selenium $1,600,1.56 \%$ vitamin A, $0.91 \%$ manganese sulfate $32 \%, 0.68 \%$ vitamin $\mathrm{E} 50 \%, 0.65 \%$ copper sulfate, $0.50 \%$ vitamin $\mathrm{D}, 0.50 \%$ mineral oil, $0.33 \%$ iodine mix $7.3 \%$, $0.23 \%$ thiamine mononitrate $99 \%$, and $0.025 \%$ cobalt carbonate. The mineral package was blended into the total diet at a rate of $122 \mathrm{~g} /$ heifer per $\mathrm{d}$ and delivered as a TMR.

${ }^{3} \mathrm{NDF}$ digestibility determined following a 48-h digestion in buffered rumen fluid.

${ }^{4} \mathrm{NFC}=100-(\% \mathrm{NDF}+\% \mathrm{CP}+\%$ ether extract $+\%$ ash $)$.

${ }^{5}$ Calculated according to NRC (2001). 


\section{Calculation of Diet Digestibility}

Digestibilities of DM, OM, NDF, and apparent N were determined for experimental diets on a whole-pen basis. The concentration of indigestible NDF after a 240-h in situ incubation was used as an internal marker to estimate fecal output. Similar procedures have been used to assess total-tract digestibilities of diets within individual lactating cows (Lee and Hristov, 2013), and diets on a whole-pen basis of Holstein heifers (Coblentz et al., 2015). During 2 consecutive days of wk 7, heifers were restrained within head-locking gates at the feed alley, and a fecal sample was collected at approximately 0800 and $1200 \mathrm{~h}$ on $\mathrm{d} 1$ and at 1600 and $2000 \mathrm{~h}$ on d 2 from each of the 8 heifers within all pens. Fecal samples were immediately composited by pen and then frozen at $-20^{\circ} \mathrm{C}$. Pen composites of fecal samples were dried to constant weight under forced air at $55^{\circ} \mathrm{C}$ and ground through a 1-mm screen. Diet and ort composites from wk 6 and 7 , as well as ground feces were then sealed in fiber bags (model F57, Ankom Technology Corp., Macedon, NY), and triplicate bags of 0.5-g samples were incubated in situ for $240 \mathrm{~h}$ within the ventral rumen of 1 nonlactating Holstein cow offered a alfalfa haylage diet $(16.7 \% \mathrm{CP}, 55.6 \% \mathrm{TDN}, 49.5 \%$ NDF; University of Wisconsin Soil and Forage Laboratory). Indigestible NDF in the in situ residues of diet, fecal, and ort samples was quantified using procedures described by the manufacturer for an Ankom200 Fiber Analyzer with both heat-stable amylase and sodium sulfite included within the NDF solution. Concentrations of ash in diet, ort, and fecal samples were determined from 1-g subsamples by combustion in a muffle furnace at $500^{\circ} \mathrm{C}$ for $6 \mathrm{~h}$, and $\mathrm{N}$ was determined by a rapid combustion procedure (AOAC International, 1998; method 990.63; TruMac CN, Leco Corporation, St. Joseph, MI). Organic matter content was calculated by subtracting the ash value from DM of samples. All calculations of nutrient digestibilities were based on DMI and orts collected during wk 6 and 7 for each pen.

\section{Statistics}

All data were analyzed by PROC MIXED procedures of SAS Institute Inc. (2011) using a randomized complete block design with 3 blocks based on initial heifer BW. In all cases, the experimental unit was the pen rather than the individual heifer, thereby permitting 8 total degrees of freedom for the statistical analysis. Dietary treatments and BW-based blocks were considered fixed variables. Logical contrasts were used to test the effects of dietary treatment; these included (1) HE versus diluted diets (STM and WS), and (2) a comparison of diluted diets (STM vs. WS). Significance was declared for $P<0.05$, and trends were reported at 0.05 $<P<0.10$.

Diet sorting data were summarized by treatments with means provided for general observation purposes without statistical analysis performed on these data.

\section{RESULTS AND DISCUSSION}

\section{Diet Formulation}

Ingredient and nutrient composition of the treatment diets and individual dietary components is presented in Table 1 . The 3 diets contained similar concentrations of CP (13.1, 12.6, and 12.6\% for HE, STM, and WS, respectively). The addition of the stemlage or wheat straw resulted in greater concentrations of DM, NDF, ADF, and ADL content, but less starch content compared with HE. Based on NRC (2001) calculations, the energy density of $\mathrm{HE}(65.4 \% \mathrm{TDN})$ was excessive for heifers of this BW range. Compared against HE, the energy density was reduced by 9.6 and $5.3 \%$ for the STM (59.1\% TDN) and WS (61.9\% TDN) diets, respectively. This was partly because of the removal of corn silage, which had high NFC content, and addition of the straw or alfalfa stemlage, which increased NDF content and reduced NFC content.

\section{Nutrient Intakes}

Nutrient and energy intakes of heifers fed the experimental diets are presented in Table 2. Both DMI and the daily intake of energy (TDN, $\mathrm{ME}, \mathrm{NE}_{\mathrm{M}}$, and $\mathrm{NE}_{\mathrm{G}}$ ) were effectively decreased with the addition of low-energy forages to the diets offered to heifers ( $P$ $\leq 0.009$ ). Heifers fed HE consumed excessive energy throughout the study, which led to over-conditioning and would lead to poor animal well-being if left on the diet for an extended period. Daily DMI did not differ within diluted diets $(P=0.607)$, but daily intakes of energy were greater for WS compared with STM $(P \leq 0.037)$. Restriction of DMI by using low-energy forages such as straw, corn fodder, or eastern gamagrass incorporated in heifer diets is well documented by previous work (Greter et al., 2008; Coblentz et al., 2012, 2015). Our results support the hypothesis that increasing low-energy forages in diets increases the rumen filling effect and results in lower DMI. Despite the lower DMI, daily intakes of NDF did not differ among all diets $(P \geq 0.110)$. Generally, lower quality feedstuff (greater NDF concentration) reduces DMI because of lower rate and extent of digestibility and greater gut fill. Quigley et al. (1986) and Tomlinson et al. (1991) reported negative correlations between NDF concentrations in the diet and DMI for growing dairy heifers, 
whenever NDF exceeded $42 \%(\mathrm{r}=-0.42)$ and $41 \%(\mathrm{r}$ $=-0.28$ ) of $\mathrm{DM}$, respectively. Based on research by Hoffman et al. (2008), the daily ad libitum DMI limit for dairy heifers is constrained at approximately $1.0 \%$ of their BW consumed as NDF. In our study, intakes of NDF were slightly lower than this constraint, based on the mean BW observed over the entire trial (0.84, 0.91, and $0.86 \%$ of BW for HE, STM, and WS, respectively). Daily intakes of starch were significantly greater for HE than diluted diets $(2.2$ vs. $1.7 \mathrm{~kg} / \mathrm{d} ; P<0.001)$, which could be explained by the higher corn silage content and greater DMI observed for HE. Difference for daily intake of starch also was observed within diluted diets $(P=0.003)$ with heifers fed WS having greater starch intake than STM. We also found greater $(P \leq 0.014)$ intakes of $\mathrm{OM}, \mathrm{CP}$, fat, and minerals $(\mathrm{Ca}, \mathrm{P}, \mathrm{K}$, and $\mathrm{Mg}$ ) for $\mathrm{HE}$ compared with diluted diets; however, only intakes of fat and Ca differed $(P \leq 0.023)$ between STM and WS. Among OM, CP, fat, and minerals, differences between $\mathrm{HE}$ and diluted diets were largely driven by DMI because concentrations of these nutrients generally varied minimally among diets.

\section{Nutrient Digestibilities}

Daily nutrient intakes based on wk 6 and 7 (Table 3) were similar to those based on the whole trial period (Table 2), with the exception of the NDF intake. The daily calculated fecal output of DM, OM, and NDF for $\mathrm{HE}$ was less than those observed for diluted diets (Table $3 ; P \leq 0.025)$. Within the diluted diets, fecal output for STM was greater than WS (Table $3 ; P \leq 0.006$ ). Calculated digestibilities of DM, OM, NDF, and apparent $\mathrm{N}$ were all greater for $\mathrm{HE}$ compared with diluted diets (Table 3; $P \leq 0.001$ ), and for WS compared with STM $(P \leq 0.001)$. Similar results were published by Coblentz et al. (2015), who explained that the higher energy diet had greater digestibilities compared with diluted diets due to greater concentration of starch and other nonfiber components in HE. The energy-diluted diets had lower digestibility due to reduced ruminal degradability of the cell walls in low-quality forages, such as alfalfa stems and straw, which accumulate high concentrations of cell-wall polysaccharides and lignin (Buxton and Russell, 1988). The lignin fraction is often considered to limit polysaccharide degradation by rumen microbes (Jung and Deetz, 1993). The digestibility of the WS diet was fairly high (60.2\% DM digestibility), possibly due to lower diet lignin content that was more comparable to HE and less than STM.

\section{Growth Performance}

Effects of the addition of low-energy forages on the growth performance of Holstein heifers are presented in Table 4. No significant differences were present in initial BW, hip height, withers height, heart girth, or $\mathrm{BCS}$ of heifers among groups $(P \geq 0.065)$. Final BW for heifers offered HE was greater than that for heifers offered diluted diets (562 vs. $543 \mathrm{~kg} ; P=0.016$ ). The gains for heifers fed $\mathrm{HE}$ are considered excessive and could potentially lead to animal welfare issues (calving

Table 2. Nutrient intakes for Holstein dairy heifers consuming diets with or without diluting agents

\begin{tabular}{|c|c|c|c|c|c|c|}
\hline \multirow[b]{2}{*}{ Item } & \multicolumn{3}{|c|}{$\operatorname{Diet}^{1}$} & \multirow[b]{2}{*}{ SEM } & \multicolumn{2}{|c|}{ Contrast $^{2}(P>F)$} \\
\hline & $\mathrm{HE}$ & STM & WS & & 1 & 2 \\
\hline \multicolumn{7}{|l|}{ Nutrient intake } \\
\hline $\mathrm{DM}, \mathrm{kg} / \mathrm{d}$ & 11.3 & 10.3 & 10.4 & 0.16 & 0.009 & 0.607 \\
\hline $\mathrm{OM}, \mathrm{g} / \mathrm{d}$ & 10.5 & 9.4 & 9.5 & 0.14 & 0.004 & 0.525 \\
\hline $\mathrm{CP}, \mathrm{kg} / \mathrm{d}$ & 1.5 & 1.3 & 1.3 & 0.02 & 0.002 & 0.672 \\
\hline $\mathrm{NDF}, \mathrm{kg} / \mathrm{d}$ & 4.4 & 4.7 & 4.4 & 0.08 & 0.202 & 0.110 \\
\hline Starch, $\mathrm{kg} / \mathrm{d}$ & 2.2 & 1.6 & 1.8 & 0.02 & $<0.001$ & 0.003 \\
\hline Fat, $\mathrm{kg} / \mathrm{d}$ & 0.31 & 0.23 & 0.26 & 0.003 & $<0.001$ & 0.002 \\
\hline $\mathrm{P}, \mathrm{g} / \mathrm{d}$ & 41.6 & 35.2 & 36.8 & 0.53 & 0.001 & 0.101 \\
\hline $\mathrm{Ca}, \mathrm{g} / \mathrm{d}$ & 98.6 & 94.6 & 86.6 & 1.57 & 0.014 & 0.023 \\
\hline $\mathrm{K}, \mathrm{g} / \mathrm{d}$ & 202.7 & 189.3 & 184.7 & 3.06 & 0.014 & 0.352 \\
\hline $\mathrm{Mg}, \mathrm{g} / \mathrm{d}$ & 53.0 & 28.9 & 29.3 & 0.43 & $<0.001$ & 0.519 \\
\hline \multicolumn{7}{|l|}{ Energy intake $^{3}$} \\
\hline TDN, $\mathrm{kg} / \mathrm{d}$ & 7.5 & 6.1 & 6.5 & 0.09 & $<0.001$ & 0.037 \\
\hline ME, Mcal/d & 29.2 & 23.2 & 25.1 & 0.33 & $<0.001$ & 0.017 \\
\hline $\mathrm{NE}_{\mathrm{M}}, \mathrm{Mcal} / \mathrm{d}$ & 19.0 & 14.3 & 15.9 & 0.20 & $<0.001$ & 0.005 \\
\hline $\mathrm{NE}_{\mathrm{G}}, \mathrm{Mcal} / \mathrm{d}$ & 12.1 & 8.4 & 9.7 & 0.11 & $<0.001$ & 0.001 \\
\hline
\end{tabular}

${ }^{1} \mathrm{HE}=$ alfalfa haylage/corn silage diet containing no diluting agent and offered for ad libitum intake; STM = alfalfa haylage/corn silage diet containing $32.1 \%$ alfalfa stem baleage (stemlage), and offered for ad libitum intake; WS = alfalfa haylage/corn silage diet containing $31.3 \%$ wheat straw, and offered for ad libitum intake.

${ }^{2}$ Contrast: 1 = HE versus all diets containing diluting agents (STM or WS); 2 = STM versus WS.

${ }^{3}$ Energy calculations based on NRC (2001). 
difficulty and poor transition to lactation) if allowed to occur for additional time. Within diluted diets, the final BW for heifers did not differ $(P=0.872)$. Similar to BW, final BCS for heifers offered HE was greater than diluted diets (3.57 vs. 3.37; $P=0.034$ ), but no difference in BCS was observed for heifers offered STM and WS $(P=0.805)$. No differences were present among diets for final withers height, hip height, or heart girth $(P \geq 0.108)$. Total BW gain (74 vs. $56 \mathrm{~kg} ; P=0.023)$ and ADG (1.32 vs. $1.00 \mathrm{~kg} / \mathrm{d} ; P=0.024)$ were greater for heifers offered HE compared with diluted diets. Changes in heart girth $(10.1$ vs. $7.0 \mathrm{~cm} ; P=0.073)$ and BCS (0.19 vs. $0.01 ; P=0.085)$ tended to be greater for heifers offered HE relative to diluted diets. The ADG for heifers offered HE was excessive $(1.32 \mathrm{~kg} / \mathrm{d})$ for normal targets recommended for Holstein heifers (Hoffman, 1997; NRC, 2001), and this was corroborated visually in the final BCS (3.57), which suggests over-conditioning. However, heifer ADG from both STM (0.96 $\mathrm{kg} / \mathrm{d})$ and WS $(1.04 \mathrm{~kg} / \mathrm{d})$ were closer to recommended targets, which means the heifer's energy requirements were more closely met when the animals consumed the energy-diluted diets that better controlled feed intake. This was also corroborated visually by the stable BCS throughout the trial period for heifers in both STM and WS groups. Similar to our result, Coblentz et al. (2015) observed that the dilution of diets with low-energy forages (wheat straw, corn fodder, or eastern gamagrass) was effective in reducing DMI and maintaining ADG within closer proximity to typical growth rate recommendations for Holstein heifers. Our findings support our initial hypothesis that the heifers would be able to meet their maintenance and growth requirements, and maintain a desirable BCS, while consuming a diluted diet. However, the feed efficiency tended to be less for heifers offered the diets diluted with low-quality forages compared with a high-energy diet (10.7 vs. 8.6 DMI/ADG; $P=0.078)$. This can be explained by the increasing physically effective fiber content in the lowenergy forage diluted diets, which reduces total-tract digestibility (Yang and Beauchemin, 2006), and thus reduces feed efficiency.

\section{Sorting Characteristics of Diets}

The distributions of TMR particle size, as well as sorting factors associated with the experimental diets, are shown in Table 5. Only general observations are provided without statistical comparisons due to the short-term 3-d sampling period. The addition of low-energy forage changed the particle size distribution relative to $\mathrm{HE}$, with increased large particles and decreased medium particles in the TMR. All particles were relatively static across sampling times for $\mathrm{HE}$, indicating heifers did not sort for or against particles across sampling times, whereas increases in sorting

Table 3. Digestibilities of various nutrients for Holstein dairy heifers consuming diets with or without diluting agents

\begin{tabular}{lcccccc}
\hline & \multicolumn{3}{c}{ Diet $^{1}$} & & \multicolumn{2}{c}{ Contrast $^{2}(P>F)$} \\
\cline { 2 - 3 } Item & HE & STM & WS & SEM & 1 & 2 \\
\hline Nutrient intake, ${ }^{3} \mathrm{~kg} / \mathrm{d}$ & & & & & & \\
DM & 11.2 & 10.4 & 10.3 & 0.20 & 0.023 & 0.710 \\
OM & 10.3 & 9.6 & 9.4 & 0.19 & 0.025 & 0.528 \\
NDF & 4.7 & 5.4 & 4.8 & 0.12 & 0.041 & 0.029 \\
N & 0.26 & 0.23 & 0.22 & 0.004 & 0.002 & 0.166 \\
Fecal output, ${ }^{4} \mathrm{~kg} / \mathrm{d}$ & & & & & & \\
DM & 4.01 & 5.35 & 4.12 & 0.166 & 0.024 & 0.006 \\
OM & 3.47 & 4.65 & 3.56 & 0.147 & 0.025 & 0.006 \\
NDF & 2.10 & 3.03 & 2.30 & 0.089 & 0.007 & 0.004 \\
Apparent N & 0.09 & 0.11 & 0.08 & 0.003 & 0.141 & 0.002 \\
Digestibility, \% & & & & & & $<0.001$ \\
DM & 64.3 & 48.6 & 60.0 & 0.54 & $<0.001$ & $<0.001$ \\
OM & 66.4 & 51.8 & 62.3 & 0.45 & $<0.001$ & $<0.001$ \\
NDF & 55.1 & 43.8 & 52.3 & 0.55 & $<0.001$ & $<0.001$ \\
Apparent N & 65.6 & 52.6 & 62.4 & 0.79 & 0.001 & 0.001 \\
\hline
\end{tabular}

${ }^{1} \mathrm{HE}=$ alfalfa haylage/corn silage diet containing no diluting agent and offered for ad libitum intake; STM = alfalfa haylage/corn silage diet containing $32.1 \%$ alfalfa stem baleage (stemlage), and offered for ad libitum intake; WS = alfalfa haylage/corn silage diet containing $31.3 \%$ wheat straw, and offered for ad libitum intake. ${ }^{2}$ Contrast: $1=$ HE versus all diets containing diluting agents (STM or WS); $2=$ STM versus WS.

${ }^{3}$ Based on wk 6 and 7 of the trial only. All calculations were based on collective DMI and orts for the entire week of analysis, and then reported on a daily per heifer basis.

${ }^{4}$ Fecal output was determined by using indigestible NDF following a 240-h ruminal incubation in situ as an internal marker. 
against large particles, and sorting for medium, short, and fine particles were observed when stemlage or straw was added to diet. Within diluted diets, heifers offered STM seemed to have more aggressive sorting for short and fine particles between 1500 and $1900 \mathrm{~h}$, compared with WS. Generally, sorting behaviors exhibited during this study were similar to those described in other studies (Hoffman et al., 2006; Greter et al., 2008; Coblentz et al., 2015). Previous work (Greter et al., 2008) demonstrated that ad libitum diets containing low-energy diluting agents are actively sorted by heifers, resulting in sorting against long forage particles. These sorting behaviors may potentially cause heifers to consume varying diets during the day causing variation of growth across animals in the pens if all animals cannot access the feedbunk, and possibly acidosis (DeVries et al., 2008); however, variation in growth was not observed for heifers fed diets containing corn fodder or straw (Coblentz et al., 2015). With the high forage and fiber content of the diluted diets, it is unlikely that acidosis would be a significant issue like that of lactating cows fed high-concentrate diets.

Several explanations are possible for the sorting behaviors with the addition of low-energy forages. First, animals may be attempting to consume feeds greater in nutrient density to meet their nutritional requirements (Kyriazakis and Oldham, 1993; Greter et al., 2008). Second, the increased proportion of long particles in the diluted diets may have encouraged increased sorting as these are easiest to sort. Hoffman et al. (2006) found that heifers preferred particles of smaller size when offered diets with top-dressed, long-stem, or bale-cut hay compared with diets where hay was shredded within the TMR mixer. Furthermore, the greater DM content of the dilutant forages (Table 1) may have led to sorting. Leonardi et al. (2005) found that lactating cows discriminated more against large particles when fed a dry TMR. The dry feedstuffs do not have the same adhesion properties as wetter forage components in the TMR. As a result, the larger, drier particles may have been more easily sorted against. Harvesting the alfalfa stems as chopped and ensiled forage or as dry hay, and then processing with a bale grinder would potentially reduce sorting issues.

\section{CONCLUSIONS}

With the addition of low-energy forages in diets offered to dairy heifers, the following conclusions have been drawn: (1) the dietary fiber content increased and energy density decreased, which reduced DM and energy intakes; and (2) heifer growth rates and body condition were better controlled, and approached recommended targets for Holstein heifers. However, it was observed that the diluted diets were more easily sorted than HE. The HE diet caused excessive growth

Table 4. Growth performance for Holstein dairy heifers consuming diets with or without diluting agents

\begin{tabular}{|c|c|c|c|c|c|c|}
\hline \multirow[b]{2}{*}{ Item } & \multicolumn{3}{|c|}{$\operatorname{Diet}^{1}$} & \multirow[b]{2}{*}{ SEM } & \multicolumn{2}{|c|}{ Contrast $^{2}(P>F)$} \\
\hline & $\mathrm{HE}$ & STM & WS & & 1 & 2 \\
\hline \multicolumn{7}{|l|}{$\overline{\text { Initial }}$} \\
\hline $\mathrm{BW}, \mathrm{kg}$ & 488 & 488 & 485 & 0.8 & 0.103 & 0.065 \\
\hline Withers height, cm & 133 & 134 & 134 & 0.5 & 0.169 & 0.681 \\
\hline Hip height, cm & 139 & 139 & 139 & 0.4 & 0.976 & 0.513 \\
\hline Heart girth, cm & 186 & 186 & 186 & 0.4 & 0.542 & 0.514 \\
\hline BCS & 3.38 & 3.35 & 3.39 & 0.05 & 0.832 & 0.650 \\
\hline \multicolumn{7}{|l|}{ Final } \\
\hline $\mathrm{BW}, \mathrm{kg}$ & 562 & 542 & 543 & 4.1 & 0.016 & 0.872 \\
\hline Withers height, cm & 136 & 137 & 137 & 0.7 & 0.556 & 0.557 \\
\hline Hip height, cm & 143 & 141 & 141 & 0.8 & 0.137 & 0.867 \\
\hline Heart girth, cm & 196 & 193 & 193 & 1.1 & 0.108 & 0.645 \\
\hline $\mathrm{BCS}$ & 3.57 & 3.36 & 3.38 & 0.05 & 0.034 & 0.805 \\
\hline \multicolumn{7}{|l|}{ Growth } \\
\hline $\mathrm{BW}, \mathrm{kg}$ & 74 & 54 & 58 & 4.1 & 0.023 & 0.492 \\
\hline $\mathrm{ADG}, \mathrm{kg} / \mathrm{d}$ & 1.32 & 0.96 & 1.04 & 0.07 & 0.024 & 0.488 \\
\hline Withers height, cm & 3.33 & 2.49 & 3.44 & 0.79 & 0.721 & 0.441 \\
\hline Hip height, $\mathrm{cm}$ & 4.02 & 1.91 & 2.54 & 0.85 & 0.160 & 0.625 \\
\hline Heart girth, cm & 10.1 & 7.1 & 6.8 & 1.07 & 0.073 & 0.858 \\
\hline $\mathrm{BCS}$ & 0.19 & 0.01 & -0.01 & 0.07 & 0.085 & 0.950 \\
\hline Feed efficiency (DMI/ADG) & 8.6 & 11.0 & 10.3 & 0.72 & 0.078 & 0.538 \\
\hline
\end{tabular}


Table 5. Particle size distribution and sorting of diets with or without diluting agent fed to Holstein dairy heifers

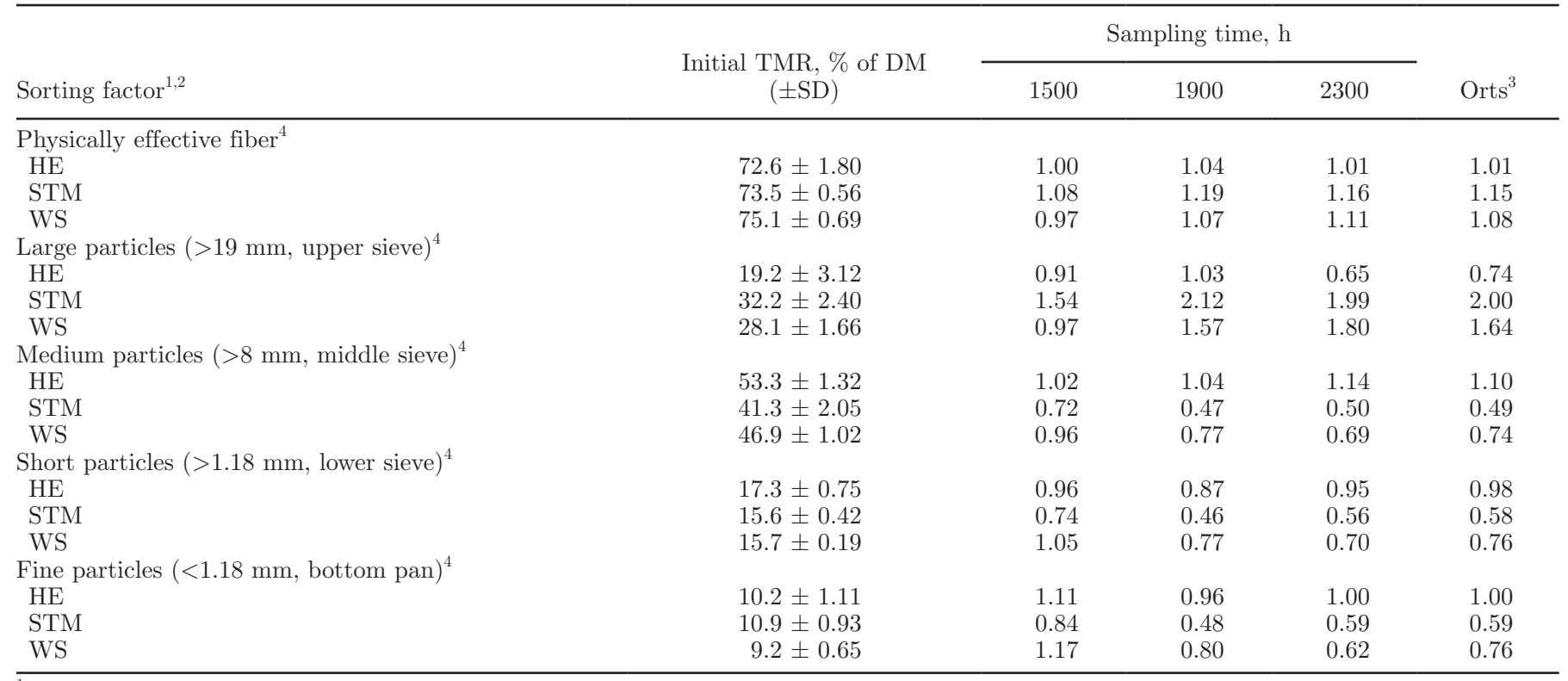

${ }^{1} \mathrm{HE}=$ alfalfa haylage/corn silage diet containing no diluting agent and offered for ad libitum intake; STM = alfalfa haylage/corn silage diet containing $32.1 \%$ alfalfa stem baleage (stemlage), and offered for ad libitum intake; WS = alfalfa haylage/corn silage diet containing $31.3 \%$ wheat straw, and offered for ad libitum intake.

${ }^{2}$ Sorting factor calculated as the concentration of large, medium, short, and fine particles (\% as fed) divided by the corresponding concentration in the original TMR.

${ }^{3}$ Orts gathered at approximately $0830 \mathrm{~h}$ each morning.

${ }^{4}$ Particle size designations determined with the Penn State Particle Separator, which has 19-, 8-, and 1.18-mm screens plus a bottom pan that retain large, medium, short, and fine particles, respectively. The physically effective fiber was defined as the percentage of particles retained on the 19- and 8-mm screens.

and over-conditioning that would potentially lead to metabolic issues at calving and into lactation. Sorting can also potentially cause variation within pens (some overfed and some underfed), thus future work to reduce alfalfa stem particle size is needed such as using chopped silage or pre-cut bales. Within diluted diets, most observed results were similar, with exception of the lower energy intake and nutrient digestibilities, and more aggressive sorting noticed for STM compared with WS. We conclude that diluting dairy heifer diets that contain high-quality forages with alfalfa stemlage or wheat straw is an effective feeding management strategy to control energy intake and maintain desirable BCS and growth rates, even though the diets were observed to be more sortable. Alfalfa stems are a potentially useful low-energy feedstuff resource to be used to replace straw in heifer feeding programs or for use in other diets that require addition of high-fiber forages.

\section{ACKNOWLEDGMENTS}

The authors gratefully thank the staff at University of Wisconsin Marshfield Agricultural Research Station and USDA Dairy Forage Research Center for their assistance in completing this project.

\section{REFERENCES}

Albrecht, K. A., W. F. Wedin, and D. R. Buxton. 1987. Cell-wall composition and digestibility of alfalfa stems and leaves. Crop Sci. $27: 735-741$.

AOAC. 1990. Official Methods of Analysis. 15th ed. Assoc. Off. Anal. Chem., Arlington, VA.

AOAC International. 1998. Official Methods of Analysis. 16th ed. AOAC International, Arlington, VA.

Buxton, D. R., and J. R. Russell. 1988. Lignin constituents and cellwall digestibility of grass and legume stems. Crop Sci. 28:553-558.

Coblentz, W. K. N. M. Esser, P. C. Hoffman, and M. S. Akins. 2015 Growth performance and sorting characteristics of corn silagealfalfa haylage diets with or without forage dilution offered to replacement Holstein dairy heifers. J. Dairy Sci. 98:8018-8034.

Coblentz, W. K., P. C. Hoffman, N. M. Esser, and M. G. Bertram. 2012. Using eastern gamagrass to construct diets that limit intake and caloric density for dairy replacement heifers. J. Dairy Sci. 95:6057-6071.

DeVries, T. J., F. Dohme, and K. A. Beauchemin. 2008. Repeated ruminal acidosis challenges in lactating dairy cows at high and low risk for developing acidosis: Feed sorting. J. Dairy Sci. 91:39583967.

Ehrman, T. 1996. Determination of starch in biomass samples by chemical solubilization and enzymatic digestion. LAP-016. US Dept. of Energy. National Bioenergy Center, Washington, DC.

Goering, H. K., and P. J. Van Soest. 1970. Forage Fiber Analyses (Apparatus, Reagents, Procedures, and Some Applications). Agric. Handbook No. 379. USDA-Agricultural Research Service, Washington, DC.

Greter, A. M., T. J. DeVries, and M. A. von Keyserlingk. 2008. Nutrient intake and feeding behavior of growing dairy heifers: Effects of dietary dilution. J. Dairy Sci. 91:2786-2795. 
Greter, A. M., B. L. Kitts, and T. J. DeVries. 2011. Short communication: Limit feeding dairy heifers: Effect of feed bunk space and provision of a low-nutritive feedstuff. J. Dairy Sci. 94:3124-3129.

Hoffman, P. C. 1997. Optimum body size of Holstein replacement heifers. J. Anim. Sci. 75:836-845.

Hoffman, P. C., N. M. Brehm, S. G. Price, and A. Prill-Adams. 1996. Effect of accelerated postpubertal growth and early calving on lactation performance of primiparous Holstein heifers. J. Dairy Sci. 79:2024-2031.

Hoffman, P. C., C. R. Simson, and K. J. Shinners. 2006. Evaluation of hay feeding strategies on feed sorting behavior of dairy heifers fed mock lactation diets. Prof. Anim. Sci. 22:71-79.

Hoffman, P. C., C. R. Simson, and M. Wattiaux. 2007. Limit feeding of gravid Holstein heifers: Effect on growth, manure nutrient excretion, and subsequent early lactation performance. J. Dairy Sci. 90:946-954.

Hoffman, P. C., K. A. Weigel, and R. M. Wernberg. 2008. Evaluation of equations to predict dry matter intake of dairy heifers. J. Dairy Sci. 91:3699-3709.

Jung, H. G., and D. A. Deetz. 1993. Cell wall lignification and degradability. Pages 315-346 in Forage Cell Wall Structure and Digestibility. H. G. Jung, D. R. Buxton, R. D. Hatfield, and J. Ralph, ed. American Society of Agronomy, Madison, WI.

Kitts, B. L., I. J. Duncan, B. W. McBride, and T. J. DeVries. 2011. Effect of the provision of a low-nutritive feedstuff on the behavior of dairy heifers limit fed a high-concentrate ration. J. Dairy Sci. 94:940-950.

Kononoff, P. J., A. J. Heinrichs, and D. R. Buckmaster. 2003. Modification of the Penn State forage and total mixed ration particle separator and the effects of moisture content on its measurements. J. Dairy Sci. 86:1858-1863.

Kruse, K. A., D. K. Combs, N. M. Esser, W. K. Coblentz, and P. C. Hoffman. 2010. Evaluation of potential carryover effects associated with limit feeding of gravid Holstein heifers. J. Dairy Sci. 93:5374-5384.

Kyriazakis, I., and J. D. Oldham. 1993. Diet selection in sheep: The ability of growing lambs to select a diet that meets their crude protein (nitrogen $\times 6.25$ ) requirements. Br. J. Nutr. 69:617-629.

Lammers, B. P., D. R. Buckmaster, and A. J. Heinrichs. 1996. A simple method for the analysis of particle sizes of forage and total mixed rations. J. Dairy Sci. 79:922-928.

Lammers, B. P., A. J. Heinrichs, and R. S. Kensinger. 1999. The effects of accelerated growth rates and estrogen implants in prepubertal Holstein heifers on estimates of mammary development and subsequent reproduction and milk production. J. Dairy Sci. $82: 1753-1764$.

Lee, C., and A. N. Hristov. 2013. Short Communication: Evaluation of acid-insoluble ash and indigestible neutral detergent fiber as total-tract digestibility markers in dairy cows fed corn-silage based diets. J. Dairy Sci. 96:5295-5299.

Leonardi, C., F. Giannico, and L. E. Armentano. 2005. Effect of water addition on selective consumption (sorting) of dry diets by dairy cattle. J. Dairy Sci. 88:1043-1049.

Lindstrom, T., and I. I. Redbo. 2000. Effect of feeding duration and rumen fill on behaviour in dairy cows. Appl. Anim. Behav. Sci. 70:83-97.
Loerch, S. C. 1996. Limit-feeding corn as an alternative to hay for gestating beef cows. J. Anim. Sci. 74:1211-1216.

Moody, M. L., G. I. Zanton, J. M. Daubert, and A. J. Heinrichs. 2007. Nutrient utilization of differing forage-to-concentrate ratios by growing Holstein heifers. J. Dairy Sci. 90:5580-5586.

NFTA (National Forage Testing Association). 2001. Moisture task force report. Omaha, NE

NRC. 2001. Nutrient Requirements of Dairy Cattle. 7th rev. ed. National Academy Press, Washington, DC

Quigley, J. D., III, R. E. James, and M. L. McGilliard. 1986. Dry matter intake in dairy heifers. 1. Factors affecting intake of heifers under intensive management. J. Dairy Sci. 69:2855-2862.

Radcliff, R. P., M. J. Vandehaar, L. T. Chapin, T. E. Pilbeam, D. K. Beede, E. P. Stanisiewski, and H. A. Tucker. 2000. Effects of diet and injection of bovine somatotropin on prepubertal growth and first-lactation milk yields of Holstein cows. J. Dairy Sci. 83:23-29.

SAS Institute Inc. 2011. SAS User's Guide. Version 9.3. SAS Institute Inc., Cary, NC.

Schulte, E. E., J. B. Peters, and P. R. Hodgson. 1987. Wisconsin procedures for soil testing, plant analysis and feed and forage analysis. Dept. Soil Sci. Bull. No. 6. University of Wisconsin, Madison.

Shinners, K. J., M. E. Herzmann, B. N. Binversie, and M. F. Digman. 2007. Harvest fractionation of alfalfa. T. ASABE 50:713-718.

Suarez-Mena, F. X., G. J. Lascano, and A. J. Heinrichs. 2013. Chewing activities and particle size of rumen digesta and feces of precision-fed dairy heifers fed different forage levels with increasing levels of distillers grains. J. Dairy Sci. 96:5184-5193.

Susin, I., S. C. Loerch, K. E. McClure, and M. L. Day. 1995. Effects of limit feeding a high-grain diet on puberty and reproductive performance of ewes. J. Anim. Sci. 73:3206-3215.

Tomlinson, D. J., R. E. James, and M. L. McGilliard. 1991. Effect of varying levels of neutral detergent fiber and total digestible nutrients on intake and growth of Holstein heifers. J. Dairy Sci. 74:537-545.

Valizaheh, R., D. M. Veira, and M. A. G. von Keyserlingk. 2008. Behavioural responses by dairy cows provided two hays of contrasting quality at dry-off. Appl. Anim. Behav. Sci. 109:190-200.

Watts, J. M., and J. M. Stookey. 2000. Vocal behaviour in cattle: The animal's commentary on its biological processes and welfare. Appl. Anim. Behav. Sci. 67:15-33.

Wertz, A. E., L. L. Berger, D. B. Faulkner, and T. G. Nash. 2001. Intake restriction strategies and sources of energy and protein during the growing period affect nutrient disappearance, feedlot performance, and carcass characteristics of crossbred heifers. J. Anim. Sci. 79:1598-1610.

Wildman, E. E., G. M. Jones, P. E. Wagner, R. L. Boman, and H. F. Troutt. 1982. A dairy cow body condition scoring system and its relationship to selected production characteristics. J. Dairy Sci. 65:495-501.

Yang, W. Z., and K. A. Beauchemin. 2006. Increasing the physically effective fiber content of dairy cow diets may lower efficiency of feed use. J. Dairy Sci. 89:2694-2704. 